\title{
INDICATORS OF THE HOUSING STOCK IN ZAGREB FROM 1945 UNTIL THE LATE 1960s
}

\author{
Lidija BENCETIĆ*
}

This paper uses Zagreb as a case study for assessing the development of a socialist city and the housing issues that this development implied. After World War II, Zagreb experienced steep demographic growth owing to a large influx of rural population, and to a lesser extent as a result of natality increase. In 1946, the city had about 270 thousand inhabitants, and in 1969 about 570 thousand. Due to the accelerated industrial development, it needed new workforce, but lacked housing, and its infrastructure was not sufficiently developed to meet the needs of all its residents. Housing construction was based on both social and private initiatives, whereby socially funded projects were multi-storey buildings and the privately funded ones single-storey houses. Due to these private constructions, that is, houses with one storey only, Zagreb resembled a village rather than a city. In assessing the housing construction of Zagreb and its urban development in general after World War II, we are inclined to agree with Davor Stipetićs statement that Zagreb arose as an architectural enterprise that lacked planning in its development.

Keywords: Zagreb, Yugoslavia, socialism, housing construction, urbanism, architecture

\footnotetext{
1 This research has been financed by the Croatian Science Foundation, project IP-2016-06-2015: Modernization of Urban Life in Croatia through the Prism of Communal Infrastructure Development in the $19^{\text {th }}$ and $20^{\text {th }}$ Centuries.

* $\quad$ Lidija Bencetić, Ph.D., Croatian Institute of History, Zagreb, Croatia
} 


\section{Introduction}

Modernisation and urban development are the key elements of survival and prosperity, or else of stagnation and extinction in any city, but they are also an area where different opinions clash about the direction and nature of development and the degree of urbanization. The state's political and social organization determines the way in which a specific city is administered and defines its decision making in management and development. Socialist societies that arose after World War II commonly based their development, including the urban development and housing, on Marxist ideology and the art practice of socialist realism, but Yugoslavia, after parting with the Eastern Bloc countries in 1948, added the principle of self-management to the Marxist ideology and replaced social realism with a new art practice - socialist aestheticism.

The changes that the new socialist regime brought to Croatia (Yugoslavia) included all segments of the society (both horizontally and vertically), social relations, organization of life and work, as well as urban planning, architecture, and housing construction. The period immediately after the war was the time when the influence of the Soviet Union on Yugoslavia was particularly evident, reflected in the ideological and artistic achievements of Croatian/ Yugoslav artists and of creative workers in general, including architects and urban planners. This was the period when they looked to the Soviet experts for their inspiration, and Yugoslav and Croatian professional architectural magazines were full of information taken from the Soviet newspapers and those of other socialist countries. During this time, politics had a crucial influence on the building profession, and political interventions went beyond general ideological channelling, often taking the form of direct political pressure. But even when such pressure was absent, architects and urban planners knew that they had to adhere to the basic tenets of Marxism and social realism in this first post-war period if they wanted to get projects and realize them. The new regime also brought a reorganization of work, and architects now gathered around large centralized project institutes (institutions), acting within them in accordance with a specific social-artistic connection based on the principles of the new political (socialist) promotion of a "unique ideological and aesthetic approach." ${ }^{2}$

In 1946, the Croatian Civil Engineering Design Institute was founded, which brought together leading Croatian architects, urban planners, and civil engineers. The purpose of the institute (project bureau) was to unite the "avail-

\footnotetext{
2 Žarko Domljan, "Poslijeratna arhitektura u Hrvatskoj" [Postwar architecture in Croatia], in: $O$ hrvatskoj arhitekturi, ed. Neven Šegvić (Zagreb: Arhitektonski fakultet Sveučilišta u Zagrebu, 1992), p. 93.
} 
able creative force." In the first post-war phase, the Institute worked on the creation of industrial facilities (factory architecture), housing construction, and the creation of socio-cultural facilities. The construction plans were part of the first Five-Year Development Plan of the Federal People's Republic of Yugoslavia, issued in 1947. It was modelled on the five-year plans implemented in the Soviet Union and aimed at accelerating the industrialization and reconstruction of Yugoslavia after the war. Architect Neven Šegvić has estimated that the first post-war period had "significant results" and that "the construction activity was greatly revived, with the beginnings of urban planning," while the architectural profession was "organized on the socialist principles, which for the architects meant the abolition of private activity." According to Šegvić, the determinants of Croatian architecture and urban planning after World War II were agreed at the 1944 conference on urbanism in Split and the 1945 Congress in Topusko, which confirmed the values of the "pre-war architectural period as a basis for the new development, with a clear definition of priorities." Apart from the design bureau (Institute), thus Šegvić, the main protagonists of post-war Croatian architecture were the Kovačić-Ehrlich studio and the Drago Ibler studio. ${ }^{4}$ Šegvić has assessed the post-war period as a "dramatic time... in which crucial issues were resolved," where results were valued more than the architects, who were pushed into the background. ${ }^{5}$

Tomislav Odak has argued that the time immediately after World War II was marked by the parallel existence of two types of tasks, one of which arose from solving existential problems - "typified housing architecture, including children's institutions, typified cultural centres, cinema theatres" - while the other aimed at "asserting and interpreting the social value system by means of buildings of exceptional importance, related to tenders launched by federal and republican state and political organizations."' Furthermore, Odak believes that Yugoslav post-war architecture did not meet the Marxist expectations and writes: "despite the numerosity and variety of the tasks imposed by the needs and the daily politics, and despite their relative successes, there was never such broadness of relations between the revolution and architecture that would have raised architecture to the level of a revolutionary act."

The Cominform resolution of 1948 and the severance of relations with the Soviet Union and the Eastern Bloc countries resulted in the discontinuity of

3 Neven Šegvić, “Stanje stvari, jedno viđenje 1945-1985." [The state of affairs, a perspective: 19451985], Arhitektura 39 (1986), nr. 196-199: 120.

4 Šegvić, "Stanje stvari," 119.

5 Ibid.

6 Tomislav Odak, "Hrvatska arhitektonska alternativa 1945-85." [The alternative scene in Croatian architecture, 1945-85], Arhitektura 39 (1986), nr. 196-199: 31.

7 Ibid., 32. 
Soviet-type constructions, albeit not immediately, the gradual de-ideologization of architecture, and the reorganization of design work, i.e. the dissolution of design institutes and the establishment of smaller, independent design bureaus. These small project bureaus or studios were based on the name and reputation of individual architects, such as Božidar Rašica, Ivan Vitić, Hinko Bauer, Antun Ulrich, Kazimir Ostrogović, or Ivo Geršić, and their work was largely related to housing architecture. ${ }^{8}$ There were also two important groups that represented the interests of small studios: Zadruga arhitekata (Architects' Cooperative), which operated through the Zagreb Architects' Society, and the Plavi 9 (The Blue 9) association, consisting of Ivo Bartolić, Miro Marasović, Stjepan Gomboš, Veljko Kauzlarić, Kazimir Ostrogović, Marijan Haberle, Franjo Bahovec, Božidar Tušek, and Antun Ulrich. ${ }^{9}$ However, the severance of relations with the Eastern Bloc countries also meant less investment and a shortage of construction materials, and thus reduced the amount of housing construction. The solution was partly sought in the production of typified buildings and in lowering the standards - organizing several housing units around a single sanitary block, omitting the kitchen, and alike. ${ }^{10}$ Art historian Žarko Domljan believes that the main causes of the housing crisis in Croatia were "the low level of technology, poor organization of work, and a lack of prefabricated building elements," which resulted in a high price of the housing units. ${ }^{11}$ Domljan has evaluated the constructions of those times as "uniform and impersonal," explaining it through the mental confusion "caused by severe ideological trauma," both after the revolution of 1945 and after breaking up with the Soviet Union in $1948 .{ }^{12}$

In the early 1950s, the political situation stabilized in the sense that Yugoslavia turned to the West and began receiving American aid and loans from the Western countries. The fear of a Warsaw Pact intervention diminished, and the more favourable political situation led to a rise in creativity, including architecture. A period of affirmation of abstract art began, with the emergence of EXAT 51 and the introduction of the new art practice of socialist aestheticism. These changes in the Croatian/Yugoslav society also affected housing construction, architecture and urban planning in general, although to a lesser extent than they affected the society at large, probably for technological and material reasons, i.e. the high costs of architectural projects and urbanization. ${ }^{13}$ Housing construction gained more momentum in the mid-1950s,

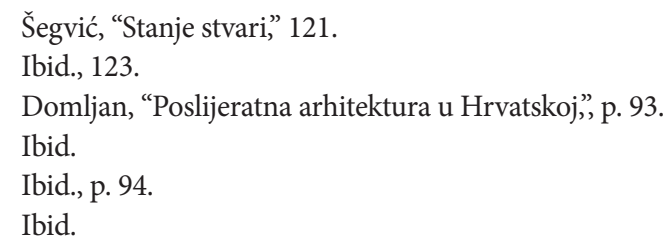


with the building of apartment skyscrapers, and the leading architects in this regard included Ivo Bartolić, Branko Tučkorić, and Milan Žerjavić. ${ }^{14}$ Žarko Domljan is of the opinion that architecture in the 1950s freed itself from its "material and ideological constraints," reaching a level "that enabled the full development of individual creativity," and that at the end of the decade it was "in a state of readiness and with open possibilities yet to be realized." 15 This indeed happened in the late 1950s and 1960s, primarily in "crossing" the Sava River and the emergence of a new part of the city - Novi Zagreb (New Zagreb). The first apartment buildings in Novi Zagreb were built in 1956/57, in the area of Savski Gaj, while the housing development of Trnsko followed in 1959.16

\section{Housing in Zagreb from 1945 until the late 1960s}

Housing construction is closely related to the economic situation of a state and the living standard of its citizens. Economically stronger countries ensure a higher standard of living to their citizens, and thus a greater need or opportunities for stronger housing construction in terms of the number of housing units, the size of apartments, and the quality of construction. By comparing the housing construction in specific countries and cities in this research, conclusions have been reached about the economic and social development of Zagreb, and thence the living standard of its citizens. Following from year to year (1945 to 1970) the housing construction in Zagreb, oscillations have been observed both in the construction and in the living standard of its citizens, resulting in part from the economic and political circumstances and in part from the population growth - rural immigration and increased birth rates. In 1946, the city had about 270 thousand inhabitants, and in 1969 about 570 thousand, so in 24 years the number of inhabitants doubled. ${ }^{17}$

The early post-war urban planning of Zagreb relied until 1953 on the prewar master plan from 1936. In 1949, the first post-war version of the master plan of Zagreb was presented, and in 1953 the second version, which defined the urbanization and development of Zagreb in the following 30 years. However, the plans from 1949 and 1953 were not ratified by the city administration due to the "insufficient ambition to expand the city and the disagreements over the solution of the railway issue." Thus, Zagreb remained without a gener-

14 Ibid., p. 95.

15 Ibid., p. 96.

16 Miljenka Fišer, "Razvoj izgradnje u Južnom Zagrebu" [Development of construction in South Zagreb], Arhitektura 27 (1974), nr. 149: 29.

17 Mirko Maretić, "Izgradnja stambenih naselja u Zagrebu" [Construction of housing developments in Zagreb], Arhitektura 24 (1970), nr. 107-108: 49. 
al master plan. ${ }^{18}$ In 1965, a new master plan was published, which was also the first urban development plan for Zagreb after World War II that was ratified by the city administration: Urbanistički program grada Zagreba: smjernice za razvoj (Urban Development Programme for the City of Zagreb: Development Guidelines). However, its level was lower than that of a regulatory basis, i.e. the general master plan. As a result, during the first twenty years of the socialist period, until 1965, Zagreb developed without any planning, and it was not until 1965 that an urban programme was adopted. This situation was a huge problem, because this was the time of steep population growth and the most significant development of the city, as well as the time when Zagreb crossed the Sava River with the rise of New Zagreb. The first general master plan of socialist Zagreb was adopted only in 1971, and due to the continued rapid development of the city, a new, second general master plan of Zagreb, which was also the last one in socialism, was adopted soon afterwards, in 1986. The extent to which socialism gave impetus to the urbanization of Zagreb is evident from the fact that in this period two general master plans were adopted, as well as three minor plans, i.e. lower-level documents, whereas in the earlier history of Zagreb's planning there were only three documents at the level of general plans - the Regulatory Basis from 1865, the Regulatory Basis from 1887/88, and the Regulatory Plan of $1936 .{ }^{19}$

Planning a city's development is one thing - the first stage - but realizing it is completely another, so from the end of World War II until the early 1970s Zagreb emerged in the following stages: the post-war buildings from the "front period", interpolated mostly on a limited number of empty "building sites in the inherited tissue of the city"; the first larger housing estates in Poljane/Vrbik; the first large representative and ambitious facilities in Grada Vukovara Street; then the five-storey and six-storey "cluster" developments in Novi Zagreb, on the south-eastern, south-western, and western outskirts of Zagreb; and the numerous apartment towers in the early 1970s. ${ }^{20}$ Mirko Maretić has an interesting observation about the planning and implementation of plans for the construction of Zagreb - "not a single housing development has been completed as a whole, that is, as conceived by a detailed master plan." He explains it by the gap between the needs and the possibilities, as he believes that architects at that time were "torn between possibilities and aspirations," and that the working conditions were "difficult". ${ }^{21}$

18 Domljan, "Poslijeratna arhitektura u Hrvatskoj”, p. 94.

19 Eugen Franković, “Urbanističko planiranje Zagreba od 1945. do 1985.” [Urban planning of Zagreb, 1945-1985], Radovi Instituta za povijest umjetnosti 1985, nr. 9: 85-87.

20 Davor Stipetić, "Stambena arhitektura ili arhitektura stambene krize" [Housing architecture or a housing crisis architecture], Arhitektura 27 (1974), nr. 149: 19.

21 Maretić, "Izgradnja stambenih naselja u Zagrebu,", p. 53. 
When it comes to the overall housing capacity of Yugoslavia, Croatia, and Zagreb, one can cite data from several authors who have dealt with this issue, and whose statistics largely coincide. Davor Stipetić states that 3,243,318 flats were built in Yugoslavia from 1946 to 1972, thereof 681,750 flats in FR Croatia and 104,397 in Zagreb. ${ }^{22}$ In a 1970 article, urban planner Mirko Maretić stated that there were 155,000 flats in Zagreb at the end of 1968 and that 79,000 flats were built between 1945 and $1970 .{ }^{23}$ Tomislav Timet writes that from the end of World War II until the end of 1954, there were 7,083 apartments built in Zagreb, and consequently he concludes that in 1955, Zagreb lacked 49,760 apartments. ${ }^{24}$ As the number of inhabitants increased, so did the need for apartments - and thus their deficit, which in 1945 amounted to 24 thousand apartments, in 1955 about 50 thousand, in 1960 about 65 thousand, and in 1970 about 80 thousand apartments. ${ }^{25}$ Maretić has emphasized the great disparity in the number of apartments built in the first ten post-war years, i.e. from 1945 to 1955, when 9,000 apartments were built, and the period from 1956 to 1970, when more than 61,000 were built. Seeking to explain this disproportion in construction, Maretić has argued that in the first period the emphasis was on the industrialization of the country and that housing construction was slow and expensive, while the method of construction was technically outdated. In the second period, new construction materials started to be used, as well as semi-prefabricated and prefabricated construction methods, while housing subsidies provided greater financial resources for construction. ${ }^{26}$

In his book on the Housing Construction in Zagreb before 1954, Tomislav Timet sharply criticizes the post-war housing construction in Zagreb, emphasizing that the whole process was very slow and that the results in the first ten post-war years were "not nearly satisfactory." From 1946 to 1949, only 88,000 $\mathrm{m} 2$ of housing area was built in Zagreb, and in the next five years a little more, but this met only $20 \%$ of Zagreb's needs, while in Yugoslavia only $12 \%$ of households had their housing needs covered in the same period. ${ }^{27}$ Timet also presents data on the increased population influx (an average of 13 thousand new inhabitants per year), which caused additional disproportion between the need of apartments and their construction in Zagreb. ${ }^{28}$ The data that shows how unsuccessful the post-war housing construction in Zagreb was (Timet

\footnotetext{
22 Stipetić, “Stambena arhitektura..., p. 19.

23 Maretić, "Izgradnja stambenih naselja u Zagrebu..., 48.

24 Tomislav Timet, Stambena izgradnja Zagreba do 1954. godine [Housing construction in Zagreb before 1954] (Zagreb: Jugoslavenska akademija znanosti i umjetnosti, 1961), p. 191.

25 Maretić, “Izgradnja stambenih naselja u Zagrebu..., p. 49.

26 Maretić, "Izgradnja stambenih naselja u Zagrebu..., p. 52.

27 Timet, Stambena izgradnja, p. 189.

28 Ibidem.
} 
uses the word "disastrous") is the number of newly built apartments per thousand new permanent residents, which Timet has compared with those from the earlier periods: from 1919-1930, it was 301; from 1931-1940, it was 426, and from 1946-1954 only 73. ${ }^{29}$ Another indicator of the poor housing conditions in Zagreb is the number of people per room. Thus, in 1954, there were 2.6 persons per room, which is identical to the data from 1918, while the most favourable situation was in 1940, with 2.1 persons per room..$^{30}$ By 1961 , the statistics had improved a bit, with 2.3 persons per room. ${ }^{31}$ The data show that Croatia lagged behind most European countries in terms of housing standards, both Western European and Eastern European ones, except for Romania and Bulgaria.

Architect and urban planner Slavko Dakić has described the rules of housing construction in Zagreb before the 1960s: apartment buildings were formed by horizontal and vertical arrays of apartments of different sizes; apartments were usually grouped along a staircase or stairwell with elevators (2 apartments or more); the height of elevators was initially limited to 4 floors (due to the elevator) in order to gradually increase, so in apartment towers today it has reached a maximum of 16 floors, occasionally more; in the beginning, traditional materials (bricks) were used, while today concrete and a number of new materials used for partitions and insulation prevail; roofs evolved from those covered with tiles to predominantly flat (passable or impassable) terraces; colour was used relatively modestly in the design of façades, which were usually flat with openings, while in the later period they were enriched with balconies and semi-closed terraces; there were often apartments on the ground floor, and there was notorious lack of space for collective use, except for strictly practical purposes (staircase, laundry rooms, garbage disposal, basement storage, etc.); there were frequent subsequent interventions on the buildings, not foreseen in the project, in terms of sun protection, expansion of the living area by enclosing the balconies and semi-closed terraces, adding apartments on the top floor, opening business premises and shops on the ground floor, and so on. ${ }^{32}$

Slavko Dakić also describes the organization of apartments: individual rooms were usually located on the same floor, with the separation of purposes (daytime, rest) in the floor plan; depending on the size of the apartment, the windows were oriented in one or two (exceptionally three) directions; individual functions were located in separate rooms, which were of very small

\footnotetext{
29 Ibid., p. 215.

$30 \quad$ Ibid., p. 219.

31 Statistički godišnjak Zagreba 1970. [Statistical yearbook of Zagreb] (Zagreb: Centar za ekonomski razvoj grada Zagreba, 1970), p. 140.

32 Slavko Dakić, "Tipično i atipično u stambenoj arhitekturi” [Typical and atypical in housing architecture], Arhitektura 27 (1974), nr. 149: 23.
} 
dimensions (except for the living room); the reduction of apartment area led to the actual disappearance of some elements, such as the hall, the utility room, etc. while minimizing others to almost unrecognizable and useless proportions (wardrobe, semi-closed terrace, and alike); on the whole, the apartment organization was very rigid and left few options for user intervention; as the floor plan was increasingly resolved within the framework of rigidly limited construction, the planned increase in housing standards in terms of floor area per capita (General Master Plan of the City of Zagreb, $25 \mathrm{~m} 2$ ) could be achieved only by gradually reducing the number of users; smaller apartments predominated and larger ones (if they appeared in practice) proved an insurmountable problem in terms of design and were resolved in the same manner as the smaller apartments (adding bedrooms along the corridor); with the development of heating technology, chimneys increasingly disappeared, which has already proved to be a serious omission in some crisis situations; in the postwar period, a high level was achieved in terms of sanitary equipment with the mandatory bathroom installation; the kitchen was arranged as a workspace, usually combined with a dining area; in relation to the relatively high degree of apartment typification, the industrial production of apartments and their individual elements was at a very low level, while the standard equipment and maintenance of apartments and buildings were unsatisfactory. ${ }^{33}$

It was in the period from 1946 to 1954 that the majority of single-storey houses were built (86.3\%), with a small percentage of two-storey buildings (5.3\%), three-storey buildings ( $2.4 \%)$, and four-storey or multi-storey buildings (6\%). ${ }^{34}$ In later years, the construction of single-storey houses remained predominant, but decreased over time, so their share in the total number of new housing constructions in 1958 was $79.48 \%$, in 1961 it was $85.88 \%$, in 1965 it was 80,05\%, while by 1969 it had dropped to $57.74 \% .{ }^{35}$ Timet is of the opinion that the housing construction took a wrong turn in Zagreb after World War II: instead of building in height, as expected in a city that was growing and striving to reach half a million inhabitants, Zagreb went wide and set a record in history to date with $86.3 \%$ newly built single-storey houses. Namely, only from 1919 to 1930 had the share of single-storey houses been almost as large and amounted to $76.1 \%$, while from 1931 to 1940 it was $73 \%{ }^{36}$ Timet cites the data that in 1954 there were 30,807 residential buildings in Zagreb, of which the largest part was single-storey (73.5\%), followed by two-storey (15.9\%), three-storey (5.6 \%) and four-storey or multi-storey (5\%).

33 Dakić, “Tipično i atipično u stambenoj arhitekturi...”, p. 23.

34 Timet, Stambena izgradnja, p. 202.

35 Statistički godišnjak Zagreba 1970., p. 142.

36 Timet, Stambena izgradnja, p. 202. 
Looking at the housing stock, Timet concludes that Zagreb had a "completely rural character" in the early 1950s. ${ }^{37}$ Mirko Maretić, as one of the main urban planners in post-war Zagreb who was among the creators of the idea of New Zagreb (South Zagreb), warned that a large city like Zagreb should go up and not constantly increase the "number of single-storey houses, which are built in unprecedented numbers," adding that "the city in its huge part still has the appearance of a village rather than a city with more than half a million inhabitants." 38

Looking at the type of apartments in the period before 1954, most of them were single-room apartments ( $45.4 \%)$, followed by those with a separate bedroom $(37.3 \%)$, the so-called private rooms $(7.4 \%)$, three-room apartments (6.1\%), studios (3.1\%), four-room apartments ( $0.5 \%)$, and apartments with five or more rooms $(0.2 \%) .{ }^{39}$ In the 1960 s, the statistics changed in favour of apartments with a separate bedroom, and thus in $1965,49.92 \%$ of such apartments were built, followed by single-room apartments $(23.74 \%)$ three-room apartments (20.22\%), apartments with five or more rooms (3.17\%), and private rooms $(2.93 \%) .{ }^{40}$ In 1969, one finds no longer data about private rooms, and the majority of apartments built were two-room apartments (44.07 \%), followed by single-room apartments (38.82 \%), three-room apartments (14.02\%), and apartments with five or more rooms (3.07\%). ${ }^{41}$ This period is also the worst in terms of the number of rooms per apartment, which was 1.52 rooms. In the earlier periods, the statistics had been more favourable: in 1900, there were 1.76 rooms per apartment, in 1919 there were 1.75 rooms per apartment, in 1930 there were 1.66 rooms per apartment, while in 1940 there were 1.61 rooms per apartment. ${ }^{42}$

Regarding the equipment of apartments in Zagreb, the data are positive only in terms of electricity supply, where statistics show that in 1950, $92.9 \%$ of apartments had electricity. In the same year, $78.7 \%$ of apartments had a kitchen, $53.6 \%$ running water, and only $35.2 \%$ a bathroom. ${ }^{43}$ The equipment of apartments was proportional to their size and the number of rooms, with the exceptions of studios built in the interwar period, where the equipment with bathroom, plumbing, and electricity was $100 \%{ }^{44}$ Data from the Statistical Yearbook of Zagreb show that the average area of an apartment in 1961

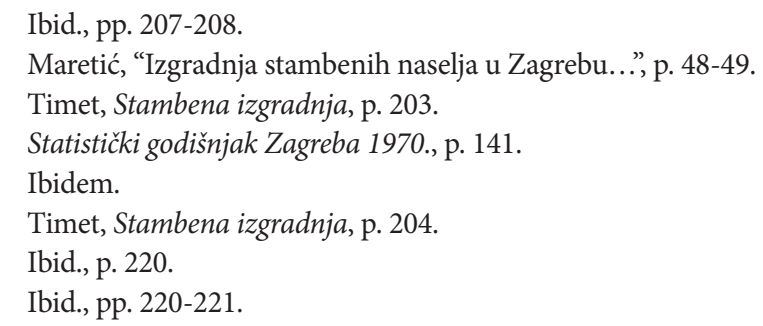


in Zagreb was $46.9 \mathrm{~m} 2$ : the average area of a single-room apartment was 32.1 $\mathrm{m} 2$, that of a two-room apartment about $54.8 \mathrm{~m} 2$, and that of a three-room apartment about $81 \mathrm{~m} 2 .{ }^{45}$ In 1970, the average size of a single-room apartment was $35 \mathrm{~m} 2$, that of a two-room apartment about $55 \mathrm{~m} 2$, and that of a threeroom apartment about $75 \mathrm{~m} 2 .{ }^{46}$ The comparative data show that the average size of a single-room apartment had thus increased by approximately $3 \mathrm{~m} 2$, the area of a two-room apartment remained almost the same, while the area of a three-room apartment had decreased by $6 \mathrm{~m} 2$.

Looking at the construction sector (private sector, general social sector, cooperative sector, and social organizations) in 1953, one can see that most housing facilities were built in the private sector $(75 \%)$, followed by the general social sector $(24.5 \%)$, the cooperative sector $(0.4 \%)$ and social organization (neglectable $0.1 \%) .{ }^{47}$ An important piece of information when assessing the housing conditions in Zagreb, which also gives a clearer picture of what the city may have looked like, is the fact that "more than $70 \%$ of residential buildings were privately owned, single-storey houses." ${ }^{\text {"48 }}$ In later years, private construction continued to dominate in the number of housing facilities: thus, in 1969 there were $85.88 \%$ private houses, and in 1965 private construction amounted to as much as $94.44 \%$, while the social sector built only $5.56 \%$ facilities. ${ }^{49}$ However, the statistical section of constructed housing facilities can be misleading if viewed in isolation, since it concerns only the number of buildings, but not the number of housing units or the total built-up area. In order to get a true picture of the situation, one should also consider the section related to the surface area of the buildings, which shows that the social sector, in fact, built more socially used area. Thus, in 1965, when $94.44 \%$ of private buildings were built, $52 \%$ of the built area was social, while in 1969 , when $85.88 \%$ of the buildings were built by private initiative, as much as $75.44 \%$ of the total built area was financed from the social sector. ${ }^{50}$ These statistics coincide with the data cited by Vlado Antolić, namely that in Croatia before the 1970s mostly multi-storey buildings (arrays, blocks, or multi-storey skyscrapers) were built, and when it comes to ownership - whether it was social (collective) or private - most buildings were private family houses, or single-storey or two-storey row houses. ${ }^{51}$ Such statistics, at the same time, con-

45 Statistički godišnjak Zagreba 1970., p. 140.

46 Maretić, “Izgradnja stambenih naselja u Zagrebu..., p. 53.

47 Timet, Stambena izgradnja, p. 224.

48 Maretić, "Izgradnja stambenih naselja u Zagrebu..., p. 48.

49 Statistički godišnjak Zagreba 1970., p. 142.

50 Ibidem.

51 Vlado Antolić, “O izgradnji stanova” [On apartment construction], Arhitektura 27 (1974), nr. 149: 16 
firm the previously cited observations that Zagreb still had a rural character in the 1950s and 1960s, and that urbanization was spatially very limited and concerned primarily socially funded constructions.

Maretić states that in 1957 in Zagreb "more than $60 \%$ of households lived in some kind of tenant or subtenant relations, with $10.6 \mathrm{~m} 2$ per person" and that many apartments were without a kitchen, bathroom, water supply, sewerage, or electricity." ${ }^{52}$ In 1961, the area per capita increased to $12 \mathrm{~m} 2 .{ }^{53}$ Maretić adds that the housing construction in this period (1945-1970) "strove only for quantity" because "it could not have been otherwise, given that the economic criteria prevailed." ${ }^{44}$ Also, he believes that the deficit of apartments in Zagreb was due to "insufficient housing construction in relation to the population growth, the influx of new inhabitants, and the dilapidation of the existing housing stock." 55

\section{Sociological assessment of housing construction in Zagreb}

Boško Budisavljević believes that most apartments built before the late 1960s have the problem of low functionality, i.e. inadequate organization, rather than that of small surface area, and that the problem of "how to use the apartment" should be resolved. ${ }^{56}$ Activities in a housing unit (apartment) are divided into regular or permanent (sleeping, eating, hygiene) and irregular or occasional (recreation, work, visits). There are also joint family activities (having lunch, watching television) and separate ones (watching television, reading, making music). These four types of activities determine the organization of the apartment area, which should primarily enable the smooth functioning of regular activities, while the areas for irregular activities should be adjusted to fit the regular ones and interference with the individual activities (regular, irregular, joint or separate) should be reduced to a minimum. ${ }^{57}$ According to Budisavljević, there is a problem of "apartment adaptability in a broader sense" in Croatia, a conclusion that he has reached by "analysing the family, the way apartments are used, financing, type of construction, and other factors" that affect the organization of housing areas. ${ }^{58}$

\footnotetext{
52 Maretić, "Izgradnja stambenih naselja u Zagrebu..., p. 48.

53 Statistički godišnjak Zagreba 1970., p. 140.

54 Maretić, “Izgradnja stambenih naselja u Zagrebu..., p. 49.

55 Ibid.

56 Boško Budisavljević, "Stanovanje nije oblikovanje" [Housing is not designing], Arhitektura 27 (1974), nr. 149: 24.

57 Ibid.

58 Budisavljević, "Stanovanje”, pp. 25-26.
} 
Melita Richter has analysed the sociological aspects of collective housing in the Zagreb neighbourhoods of Kalinovica, Knežija, and Srednjaci. She has concluded that such forced collective housing "has negative rather than positive repercussions," which is expressed in feelings of resentment and closedness towards the neighbours, whereby the "social contacts 'at a distance' acquire a tone of intolerance and ridicule" while the constant focus on "the same physical structure results in a feeling of monotony". Furthermore, due to the way these buildings are built, with poor sound insulation, low ceilings, and thin walls, the neighbourly relations within the building are often characterized by "intolerance and perceiving the other as interference". ${ }^{59}$ Richter extends this conclusion to almost the entire collective housing construction in Zagreb and Croatia, and states that, "since the modern construction methods in terms of building materials and spatial organization is mostly similar and standardized, it may be said that (...) it is systematically present in modern housing of the collective type." ${ }^{\prime 6}$ In her research, Richter surveyed the residents of the said neighbourhoods and found that $70 \%$ of the respondents complained that "there are no elements that would make the area of a new settlement more humane, specific, less monotonous, and less insignificant." ${ }^{61}$ Richter also believes that "restraining the creative expression of individuals and hindering their influence on their living space and is a big mistake of present urbanism. If it starts at the level of the building, it is not to be expected that something else will happen at the level of neighbourhood. Therefore, the logical sequence of such an attitude is that the inhabitants treat the public areas and the common intentions as a 'no man's land'." 62 Richter eventually concludes that "the element of personalization and adoption of space is absent at all levels, which largely emphasizes the feeling of monotony and sadness in the new neighbourhoods." ${ }^{\text {3 }}$

\section{Conclusion}

The housing construction in Zagreb from 1945 to the end of the 1960s was largely conditioned by the consequences of World War II (devastation and poverty); the foreign policy of Yugoslavia, which directly influenced the

\footnotetext{
59 Melita Richter, "Sociološki aspekti tipa kolektivnog stanovanja na primjeru naselja Kalinovice, Knežije, Srednjaka" [Sociological aspects of collective housing: The case of Kalinovica, Knežija, and Srednjaci neighbourhoods], Arhitektura 27 (1974), nr. 149: 27.

60 Ibid.

61 Ibid., p. 28.

62 Ibid.

63 Ibid.
} 
quantity and type of construction materials; the ideological foundations of Marxism, self-management socialism, social realism, and socialist aestheticism; population influx and increased birth rates; and the expertise of designers, architects, and contractors.

The general characteristics of housing construction in Zagreb were the constant lack of financial resources; the lack of housing facilities and apartments due to increased population influx and birth rates; poor quality of housing facilities due to the lack of finances and contractor expertise; illegal construction of single-storey houses that gave the town the appearance of a village; and the social financing of housing in the form of multi-storey buildings.

As a concluding thought on the housing construction in Zagreb, we would like to refer to an observation of Davor Stipetić, who believes that Yugoslav post-war architecture as a whole was and remains an enterprise that did not fail even worse than it did "perhaps only because of the profound creative enthusiasm that many architects brought into it." ${ }^{34}$ According to Stipetić, it is ironic "that the cities of our ancestors who lived in times of social disaster were created in a planned way, while our cities - products of a society that plans its own future - grow in disarray." 65

\section{Bibliography}

\section{Primary sources:}

Statistički godišnjak Zagreba 1970 [Statistical yearbook of Zagreb 1970]. Zagreb: Centar za ekonomski razvoj grada Zagreba, 1970.

\section{Literature:}

Antolić, Vlado. "O izgradnji stanova” [On apartment construction], Arhitektura 27 (1974), nr. 149: 16-18.

Budisavljević, Boško. "Stanovanje nije oblikovanje" [Housing is not designing], Arhitektura 27 (1974), nr. 149: 24-26.

Dakić, Slavko. "Tipično i atipično u stambenoj arhitekturi” [Typical and atypical in housing architecture], Arhitektura 27 (1974), nr. 149: 23.

64 Stipetić, “Stambena arhitektura,": 20.

65 Stipetić, "Stambena arhitektura,": 21. 
Domljan, Žarko. "Poslijeratna arhitektura u Hrvatskoj” [Post-war architecture in Croatia]. In: O hrvatskoj arhitekturi, ed. Neven Šegvić, 91-99. Zagreb: Arhitektonski fakultet Sveučilišta u Zagrebu, 1992.

Fišer, Miljenka. "Razvoj izgradnje u Južnom Zagrebu" [Development of construction in South Zagreb], Arhitektura 27 (1974), nr. 149: 29-31.

Franković, Eugen. "Urbanističko planiranje Zagreba od 1945. do 1985." [Urban planning of Zagreb, 1945-1985], Radovi Instituta za povijest umjetnosti (1985), nr. 9: 85-87.

Maretić, Mirko. "Izgradnja stambenih naselja u Zagrebu" [Construction of housing developments in Zagreb], Arhitektura 24 (1970), nr. 107/108: 48-59.

Odak, Tomislav. "Hrvatska arhitektonska alternativa 1945-85." [The alternative scene of Croatian architecture 1945-85], Arhitektura 39 (1986), nr. 196-199: 31-101.

Richter, Melita. "Sociološki aspekti tipa kolektivnog stanovanja na primjeru naselja Kalinovice, Knežije, Srednjaka” [Sociological aspects of collective housing: The case of Kalinovica, Knežija, and Srednjaci neighbourhoods], Arhitektura 27 (1974), nr. 149: 27-28.

Stipetić, Davor. "Stambena arhitektura ili arhitektura stambene krize" [Housing architecture or a housing crisis architecture], Arhitektura 27 (1974), nr. 149: 19-22.

Šegvić, Neven. "Stanje stvari, jedno viđenje 1945-1985." [The state of affairs, a perspective: 1945-1985], Arhitektura 39 (1986), nr. 196-199: 118-127.

Timet, Tomislav. Stambena izgradnja Zagreba do 1954. godine [Housing construction in Zagreb before 1954]. Zagreb: Jugoslavenska akademija znanosti i umjetnosti, 1961. 
